\title{
The Business Model of a Buddhist Monasticism: Acquiring Productive Assets
}

\author{
GREGORY SCHOPEN \\ University of California, Los Angeles \\ schopen@bumnet.ucla.edu
}

Keywords: Vinaya, monastic property, Indian Buddhism, medieval India, monastic labour

DOI: https://dx.doi.org/10.15239/hijbs.02.02.08

Abstract: Whatever else the Buddhist monastic community or Sangha was in early and medieval India, it was certainly an institution with economic interests and concerns. At least one of its monastic Codes or vinayas presents it as a legal or juristic personality that owned property - both real and movable-and as a corporation that was intended to generate wealth. The authors or redactors of that same Code invented, developed, or used a whole series of sophisticated legal and financial instruments (permanent endowments, indirect deposits, written wills, etc.) and fundraising techniques (organized and advertised fund drives, etc.). It also authorized the engagement of its monks in a wide variety of business ventures, and framed rules governing such enterprises as selling rice under market value, dealing in expensive cloth, providing hospice care, etc.). All of this will be surveyed, paying particular attention to the justification and rationalization of these practices, and how they embedded the monastery in the local economies—both agricultural and commercial—so that the monastery had vested interests in the local economy, and the economy had the same interests in the monastery. 
$\mathrm{I}$ t has often been assumed or asserted that what we call Buddhism started in India with small groups of possessionless, wandering ascetics without a permanent home. Very early literature like the Rhinoceros and Muni sütras have been taken to support this, and they may actually do so, as might some of what Aśoka had to say, as well as the all-but-blank archaeological record for the very earliest periods. But if this scenario is even remotely correct, how Buddhist groups moved from this state of affairs and became wealthy landowning corporations-in effect businesses - remains a mystery. Nālandā owned and managed more than two hundred villages by the end of the seventh century, and this included, of course, the people that lived in them. ${ }^{1}$ There is, alas, no direct evidence explaining this transformation, but there are some indications in the literature that their authors were aware of a change. In the same literature, there are a number of stories that some monks told other monks about how some of these changes occurred. Such stories need not be-and probably are not-particularly accurate. They will be important not because they can tell us what actually occurred, but because they will reveal how their monk authors thought, or wanted other monks to think, certain things that they were doing then had come to be, and even more importantly, why these things had come to be. In effect, these stories indicate how monks explained things to themselves.

One such story is particularly interesting because it seems to capture a key moment in this transition and presents, in effect, the very moment that things turned under the direction of the Buddha himself and what he had declared. ${ }^{2}$ It occurs in the Bhaisajyavastu of the Mülasarvāstivāda-vinaya. In the Sanskrit version of this vastu found at Gilgit we find:

Then a large number of monks, when the three months of the rain retreat had passed and their robes were made up and finished, taking their bowls and robes approached the Blessed One. Having

\footnotetext{
1 Takakusu, Record, 65.

2 For other views of the key moment or moments see Foucher, La vie, 23940; Gernet, Aspects, 73-74; Gernet, Buddhism in Chinese Society, 77-78.
} 
approached, having venerated with their head the feet of the Blessed One, they stood to one side. Standing to one side that large number of monks said this to the Blessed One: 'We, Reverend, have stayed for three months [for the rainy season retreat] in Vairambhya'. ${ }^{3}$

In the Gilgit manuscript, instead of the text continuing, the reader is instructed at this point:

\section{vistarena vairambhyasütram ekottarikāgame catuskanipäte /}

(Supply) in full (the text of) the Vairambhyasutra (found) in the Section of Fours in the Ekottarikägama.

There are a number of other instances of exactly the same thing in this vastu (93.10, 111.20, 112.19), as J. W. de Jong noted long ago, ${ }^{4}$ but it remains unclear how best to describe what has occurred: it is not yet clear whether this Vinaya was in the process of absorbing the sütras, as de Jong thought, or the sütras are in the process of being stripped out of their original location in the Vinaya. ${ }^{5}$ One thing that is virtually certain, however, is that the Sanskrit text that was translated into Tibetan did not (yet) have either these instructions or any abbreviation. There, the text is continuous with no indication at all that it was an old sütra found elsewhere. The Tibetan text reads:

Then when a large number of monks had passed the three months of the rain retreat, when they had made up and finished robes, they went to the Blessed One, and arriving there, and venerating with their head the feet of the Blessed One they sat down to one side. When seated to one side that large group of monks said this to the Blessed One: 'Reverend, since we have been for three months (of the rains) in Vairambhya we will now destroy the huts (kuti)'.

'Monks, you must not destroy the huts! For as long as they remain, for so long is there an increase in the merit for the donor

\footnotetext{
3 Bhaișajyavastu, Dutt, Gilgit Manuscripts, Vol. III, 1, 45.13.

4 De Jong, 'Les sūtrapițaka', 400-01.

5 Schopen, 'Hierarchy and Housing', 93-94.
} 
(dannapati), a growth in the merit. These four things should be known as a continuous flow of merit for a benefactor and donor, a continuous flow of good, a basis for ease (dāyakasya dānapateh punyābhisyandạ kusalābhisyandạ sukhāsvādadhārah). ${ }^{6}$ Which four? When a monk possessed of virtue and abiding in good practice dwells in someone's dwelling (vihära), and while dwelling there experiences bodily the immeasurable concentration of mind and perfects it, on account of that it is to be known that for that benefactor and donor this is a continuous flow of merit, a continuous flow of good and an immeasurable basis for ease. And as it is in regard to a dwelling (vihära), so it is also the same for robes, alms and bedding and seats. ${ }^{7}$

Most of this little text-not all of which is cited here-has close parallels or variants elsewhere. The frame-story, though, does not, and the first paragraph here is unique to the version found in the Mülasarvastivāda-Vinaya. It is the frame-story, however, that captures the moment of transition. Narratively, the monks' initial impulse was to dismantle the huts at the end of the rain retreat, to remain unencumbered with real property and-by implication-its management and maintenance. According to the monk redactors of this account, the Buddha himself then directly intervened to block the impulse and to irrevocably alter the lifestyle of this 'large group of monks'. According to the account here, the Buddha did so not on account of the monks, but to benefit their benefactors and donors; to provide them with a predictable ongoing source of merit, a kind of-if you will-perpetual merit machine. As long as the vihära that a donor makes available continues to be used by a monk who is seriously engaged in pursuing the religious life, so long does merit continue to accrue to the donor. The logic here seems to be very

6 The Sanskrit is supplied from Pradhan, Abbidharmakośabhāsyam, 197.26, where some version of the text is quoted as sūtra uktam; see also de La Vallée Poussin, L'Abhidharmakośa, T. III, 20.

7 Bhaisajyavastu, Derge 'dul ba Kha 144b.1-145a.4. All citations of and references to canonical Tibetan sources are from or to Barber, Tibetan Tripitaka. 
much like that which lies behind the gift of an image: the gift is not of a simple object-it is the gift of an opportunity for others to worship and make merit. The donor of the image makes possible each and every act of worship directed toward it, and each act therefore constitutes a new or additional gift. As long as the image continues in use, so long does it continue to make merit for its original donor. ${ }^{8}$ Seen in this light, it is evident that by providing shelter, the donor of a vihāra, quite literally makes the good monk's progress possible. As long as he continues to use that vihära and to engage in 'good practice', so long does the donor continue to contribute directly to the monk's religious life. This sort of thinking will—in a variety of different forms - continue to occur over and over again in this enormous Vinaya. In some places, as we will see, the importance of 'use' will be made much more explicit and we will repeatedly encounter the expression paribhogānvayam punyam, 'merit following from use'. Additionally, given what their gifts might do for them, donors might well be concerned that their gifts might be used for as long as possible, and our redactors will also repeatedly address this concern in a variety of ways. This concern is, for example, the reason given by our redactors for the rule requiring monks to lend money on interest.

But if the story that the redactors of this Vinaya told their monks about how they came to own permanent 'huts', or vihäras, turned on the idea of monks benefiting their donors by continuing to use what they had given, this same idea-expressed in a slightly different way-is expressed as well in the story of how they came to own villages, land, oxen, buffalo, goats and sheep. The story is a remarkable one and may even be unique in its account of how the authorization to accept such things came about. It occurs in the Ksudrakavastu and is relatively long: ${ }^{\text {? }}$

Then king Pradyota [of Avanti], having distributed jewels to the five chief limbs [of his kingdom], went to the Venerable Mahākātyāyana, and arriving there he venerated with his head the feet of the Vener-

8 Schopen, Bones, Stones and Buddhist Monks, 66-67.

9 Ksudrakavastu, Derge 'dul ba Da 15a.7-16b.2. 
able Mahākātyāyana and sat down to one side. When seated to one side king Pradyota said this to the Venerable Mahākātyāyana: 'The Noble One is one who effects benefit and great favor. If on that account I give the kingship (räjya) to the Noble One, might he out of kindness accept the kingship?'

The Venerable Mahākātyāyana said: 'Great King, the Blessed One has prohibited the exercise of kingship for a monk.'

The king said: 'Noble One, if that is so, when I give all that you desire, might you enjoy (parivbhuj) all your desires?'

He said: 'Great King, the Blessed One has also prohibited all desires.'

The king said: 'Noble One, if that is so, when I give the means of subsistence (longs spyod, paribhoga) and the auxiliaries of the means of subsistence (longs spyod kyi mchog), might you make use (parivbuj) of them?'

He said: 'Great King, if the Blessed One were asked it is to be done.'

The king said: 'Do so, Noble One!'

While distributing his largesse, the king makes some fairly grandiose offers to the monk Mahākātyāyana, which the good monk immediately declines. But when offered the 'means of subsistence' and their auxiliaries, he hesitates. 'Means of subsistence and 'auxiliaries' are only approximate translations, and it is unclear to what they refer. The redactors must also have thought this unclear since later in the text they have the Buddha himself define them: the 'means of subsistence' are villages and fields, the 'auxiliaries' are oxen and such which the fields require to be productive. It is also worth noting that when the king indicated to the monk that he should consult the Buddha, this is not as straightforward as it might seem. Pradyota was the king of Avanti and his conversation with Mahākātyāyana presumably took place there. But in the geography of the Mülasarvasstivāda-vinaya Avanti is a remote border region far to the west of the Buddha's range. In fact our text resumes by saying:

At that time the Blessed One was staying in Śrāvastī, in the Jetavana, in the park of Anāthapiṇ̣ada. 
A journey on foot from Avanti to Śrāvastī would be long and this was ordinarily the only way that monks travelled, but in this caseand again, this case may be absolutely unique-a trip turned out to be unnecessary. Immediately following the statement of the Buddha's location there is an editorial comment that says:

In such a case there is not even the slightest thing that Buddhas, Blessed Ones, do not know, do not see, are not aware of and do not discern (atrāntare nāsti kiñcid buddhānām bhagavatām ajn̄ātam adrsțtam aviditam avijñätam $)^{10}$

This editorial insertion is a part of a very widely attested cliché, and like all such insertions it was meant to explain to the reader what was about to happen. Here some explanation was needed because the text was about to say, in effect, that in spite of the great physical distance, the Buddha was fully aware of what Kātyāyana was thinking and doing:

The Blessed One, observed (samlakșayati): 'the monk Mahākātyāyana is not endeavoring to acquire the means of subsistence and the auxiliaries of the means of subsistence but rather the benefit (anugraba) of Western men.' Mentally observing this he then produced a thought concerning the world.

Then follows a second editorial insertion meant, it seems, to prepare the reader for an even more unusual course of events:

It is a rule (dharmatā) that when Buddhas, Blessed Ones, produce a thought concerning the world (laukikam cittam) then living creatures, even small ants, are aware in their minds of the thought of the Blessed One. When they produce a thought which goes beyond the world then even disciples and self-awakened ones (pratyekabuddha) are not aware in their minds of the thought of a Blessed One, how much less those born among animals.

\footnotetext{
10 The Sanskrit is supplied from the set-phrase listed in Hiraoka, Setsuwa, 172.
} 
Even this, however, was not enough to allow the redactors to establish direct contact and communication between the Buddha in Śrāvastī and Mahākātyāyana in far-away Avanti, so it was immediately added:

In this instance a thought concerning the world was produced which was transmitted in the thought and mind of the Blessed One and the Venerable Mahākātyayyana. Then the Blessed One and the Venerable Mahākātyāyana, having brought into effect the divine eye (divyacaksus) and the divine ear (divyaśrota), began to both see and hear each other. Then the Venerable Mahākātyāyana said this to the Blessed One: 'Reverend, is it proper for a monk to accept for the sake of the community (saigha) the means of subsistence and the auxiliaries of the means of subsistence?'

The Blessed One said: 'Mahākātyāyana, because it is out of concern (anukampā) for Western men, because it will increase the use (paribhoga) for donors (dāyaka), it is proper. Therefore, the means of subsistence and the auxiliaries of the means of subsistence are authorized for the Community, but not for an individual. Here the means of subsistence are these: villages and fields. The auxiliaries of the means of subsistence are oxen, buffalo, goats and sheep.'

The Venerable Mahākātyāyana, having asked the Blessed One, said to King Pradyota: 'Great king, because of concern for Western men, and because it will increase the use for donors, the Blessed One has authorized the means of subsistence and the auxiliaries of the means of subsistence for the Community.'

King Pradyota, then, with assistance from Mahākātyāyana had a vihära built which was complete with all the accoutrements, and when he had given it to the Community of Monks of the Four Directions (caturdisabbiksusamgha) he also gave the means of subsistence and the auxiliaries of the means of subsistence.

There are several points worth pondering here, not the least of which is the curious, indirect, and virtually telepathic way in which this ruling was sought and delivered. The Buddha's omniscience is a narrative cliché in this literature, and the divine eye and ear are also well-known, but their use here is unusual, if not, again, unique: I know of no other case in which a rule or authorization is delivered 
in this way. Notice that the ruling was not made publicly, nor was it presented by the Buddha directly to the monks. All this might indicate some unease on the part of the redactors about what they were delivering. The wording of the ruling might also seem almost euphemistic and indicate the same: to say 'the means of subsistence and the auxiliaries of the means of subsistence are authorized' when it is perfectly clear and explicitly stated that the Buddha authorized the acceptance and ownership of villages and fields, oxen and buffalo, seems oddly indirect. Any unease, however, seems to have disappeared by the time that Gunaprabha digested our text. He says straightforwardly:

\section{pratigrhnūiyāt samghārtham grāmān / kșetrāñ ca / ${ }^{11}$}

He should accept, for the sake of the Community, villages / and fields.

If, however, the discomfort with Buddhist monks and monasteries accepting and owning villages and fields is ours, and not the redactors', then the issue emerges in another form. The curious telepathic promulgation was likely necessary because of the narrative fact that Mahākātyāyana and Pradyota were in Western India while the Buddha was in Śrāvastī, far to the East. But there may also be a particular reason for setting the account in Avanti even though this created communication difficulties and unusual elements in the story. It is possible that the account was set in Western India because the redactors associated Mahākātyāyana and Western India with concessions to previous or normal monastic practice. The Carmavas$t u$ - a completely different section of this enormous Vinaya-gives an account of how Mahākātyāyana sought and received a series of modifications to standard monastic practices because of local practices and conditions from Western India: ordinations could take place with less than a quorum of ten; monks could bathe frequently, wear certain types of sandals, and so forth. In this case, the communication between Mahākātyāyana and the Buddha was considerably more

\footnotetext{
11 Sankrityayana, Vinayasūtra, 95.29.
} 
conventional-a disciple of the Buddha who was going on foot to 'see' the Buddha carried his request. ${ }^{12}$ By linking the account of the acceptance of villages and fields with Kātyāyana and Western India, our redactors - whether intentionally or not-would have associated it with this other account in which concessions were made to local practices in Western India. Notice that the text seems to go to some trouble to indicate that Mahākātyāyana was acting for 'the benefit of Western men', and that the Buddha authorized the practice 'out of concern for' those in the West. There is here, however, one final consideration: it is possible that this account is a kind of historical memory on the part of the redactors and that they knew the practice of accepting villages and fields originated elsewhere-in Western India. In fact, the earliest surviving inscriptional records of the gift of fields and villages to Buddhist establishments come almost exclusively from Western India, and they are many: two from Kanheri, six from Nasik, three from Karle, one from Kuda, six from Junnar. Some typical examples, which also show indirectly how monastic land was utilized, are Nasik No. 9:

Of Mugūdāsa, one of the lay brothers of Chetika (chetika-upāsakiyasa), together with his dependents, the cave (or: residential cell: lena) is the religious gift (deyadhama).

For this cave (or: cell) the son of the lay brother Bodhiguta, Dhamanamdin, has given a field (kheta) in Western Kanhhahini.

And from (the rent/ produce of) this (eto) field cloth-money (civarika)(is to be provided) for the renouncer (pāvaita) (who stays there). ${ }^{13}$

Or Kanheri no. 18:

Success! Of the son of the merchant (negama) Golanaka from Kalyāna, the merchant Isipāla, together with his dependants (and) as an act of worship for his mother and father (mätäpitunam puyatha),

12 Carmavastu, Dutt, Gilgit Manuscripts, Vol. III, 4, $185 \mathrm{ff}$.

13 Senart, 'Inscriptions in the Caves at Nasik', 77. 
a cave (or residential cell, lena) and a cistern are the religious gift (deyadhamma).

And a permanent endowment (akhayanivi) was given, (to wit:) a field (kheta) situated in the village of Saphau.

And from (the rent/produce of) that (eto) the sum of twelve (bärasaka $=d v \bar{a} d a s a k a)$ as cloth-money (civarika) for one who resides (there) for the rains, and the amount of one kärșäpana a month in the hot season. With the remainder (things) in the mandapa and pravada are to be kept in order. ${ }^{14}$

In both examples, while we do not know what was planted in the fields, it is perfectly clear what they were expected to produce: money. 'From this field civarika', and there is no doubt about what civarika means. The term is regularly translated into Tibetan as gos kyi rin 'the price of robes/cloth', and repeatedly defined in our code: gos kyi rin dag ces bya ba ni gser ram dngul lo 'in regard to the word civarika the meaning is gold or silver'. ${ }^{15}$ Obviously gold and silver do not grow in a field and for the fields to produce them they would have to be rented out, or their produce would have to be sold and converted into cash. Either or both would necessarily involve the monastery, and at least some monks in business and administrative affairs. Clearly the Buddha's ruling that villages and fields must be accepted, like his ruling with regard to maintaining permanent structures, would have long-term and far-reaching consequences for Buddhist monastic groups.

What we have, then, in this account of the acceptance of fields and villages is another key moment in the story that our monastic redactors told their monks about how they had become what they were, another step in the move from possessionless to propertied. The first step was-according to the story - taken by the Buddha to ensure donors and benefactors of an ongoing, continuous source of merit by insisting that their 'gift' continue to be used. But the second step too was justified in terms of 'use'. First of all, when Pradyota makes

\footnotetext{
14 Burgess, Report on the Elura Cave Temples, 81-82.

15 Bhikșu-vibhanga, Derge 'dul ba Cha 114 b.1, 118a.3, 125 a.7.
} 
his initial offer he requests Kātyāyana to 'make use' (pari\bhuj) of what he is making available. Then we are told that the Buddha himself observed that Mahākātyāyana was not actually after villages and fields, but 'the benefit of Western men'. Then we are told not once, but twice, that villages and fields were authorized 'because it will increase the use (paribhoga) for donors (dāyaka)'. Both steps were taken, in effect, for the same reasons, and in both cases the idea of 'use', while expressed differently, would appear to have been determinative. There are, however, at least two more stories that monks told each other to explain how they became propertied, and how they came to be engaged in business.

One of these additional stories delivers an authorization for monks to consume yavāgu. Although frequently translated as 'conjey' or 'congee', sometimes as 'gruel', what precisely this was is not certain. It was almost certainly a kind of porridge or soup made from some kind of grain. Unlike 'gruel' it appears in our text as if it were considered a delicacy and our Vinaya has a special monastic officer who is in charge of its distribution, the yavägücäraka. ${ }^{16}$ The text occurs in the Muktaka section of the Uttaragrantha. ${ }^{17}$

When the venerable Śroṇakotivimịsa had become pale, haggard, weak, exhausted, physically spent, and the Blessed One saw that he said to the Venerable Ānanda: 'Why, Ānanda, has Śroṇakoțiviṃśa become pale, haggard, weak, exhausted and physically spent?'

'He, Blessed One, is one who from when he was first born has nursed his body only with yavāgü,' Ānanda said.

And then the Blessed One said: 'Therefore, Ānanda, since I authorize it, Śronakoțivimśa must be given yavāgū to eat!'

The venerable Ānanda then informed Śroṇakoțivimśa: 'Venerable Śronakotịivịśa, the Blessed One has authorized in regard to you that yavāgü must be eaten!'

He said: 'Reverend Ānanda, for me alone or all the Community?'

Ānanda said: 'For you alone.'

16 Gnoli, Gilgit Manuscript of the Śayanāsanavastu, 55.23.

17 Uttaragrantha, Derge 'dul ba Pa 182b.5-183a.5. 
'But, Reverend Ānanda, if this comes to be talked about even my fellow religious will say 'Śronakoțivimiśa once, before he had entered the religious life in the order, and when there was an abundance of food in Campā, rejected even what could be pulled by seven oxen, and yet now, when he has entered the religious life he only indulges in yavaguñ!' On that account, if for my sake the Blessed One will authorize yavāgu for all the Community as well I too will now eat it!'

The monks reported to the Blessed One what had occurred, and the Blessed One said: 'therefore, since it is authorized for the sake of Śronakoțivimśa, all the Community as well must eat yavāgū!'

When King Bimbisāra heard 'the Blessed One has authorized that the Communities must eat yavāgu' he gave to the Community fields of a size that could be sown with a thousand measures of seed. But when the monks did not accept them the Blessed One said: 'If it is for the sake of the Community they must be accepted and in regard to this have no doubt! Further, what is produced from the field must be used (bhogya) by the Community!

The promulgation here of a general rule on account of a single monk is unusual but not without parallel. In the Bhaisajyavastu for example, when the monk Vairatțasimha cannot achieve one-pointedness of mind (cittaikāgratā) because of foul odors in his vihāra, the Buddha authorizes that his vihära, and that of others like him, should be adorned with perfumes, garlands, incense and aromatic powders. ${ }^{18}$ Since, moreover, both the acceptance of fields and the consumption of yavāgu are referred to elsewhere, at first glance it is also not entirely clear what this promulgation was intended to authorize. It may have been intended here to provide authorization of a specific kind of field: fields on which grains used in making yavāgu could be grown. The authorization from the Ksudrakavastu discussed above was for generic fields, and did not specify that what those fields produced must be used or consumed by the Community itself. If the original of this Muktaka passage actually read bhogya it could have meant either, and the concluding rule here would have

18 Bhaișajyavastu, Dutt, Gilgit Manuscripts, Vol. III, 1, 223.7. 
been that the Community itself must consume or eat what the fields produced. But either way, once again we have an emphasis on 'use', and this aspect of the motive is even more pronounced in what appears to be a reference to this promulgation found later in an entirely different section of the Uttaragrantha. It says, using a formula or set phrase that will be repeatedly encountered:

The Blessed One authorized yavāgu for the monks so that they experience ease, and so that the religious gifts of donors and benefactors are used (sukhasparśavihārārthaụ dāttrīnām ca deyadharmaparibhogārtham $)^{19}$

If the story of Śronakoțivimśa delivers the rule that, in effect, the gifted field must be directly exploited by the monastic community, and that the monks must consume what the fields produce, that still leaves the question of who actually worked the fields and made them productive. Monks in this Vinaya were allowed-in some cases required-to engage in certain forms of labor under certain circumstances: leather work, the work of a smith, barbering, and construction work, ${ }^{20}$ but never, as far as I know, farming or agriculture, and the redactors seem to have had a very negative view of it. There is also a Prätimokșa rule making it an offence for a monk or nun to dig the earth or even have others do so, although it is a very minor one (payyantika). ${ }^{21}$ In the rare reference to working a monastic field it is not a monk who does so-the monk is said to 'have' the field plowed, but who he has do the plowing is unstated in a text we will see again (dge slong gzhi pa zhig dge 'dun gyi zhing rmed $d u$ bug pa). ${ }^{22}$ Our redactors, however, knew or imagined monastic communities that had a very considerable servile workforce: they, and the redactors of some other Vinayas, tell a story about a monk

19 Uttaragrantha, Derge 'dul ba Pa 285b.7. The Sanskrit is supplied from the Varșāvastu, Shōno, 'A Re-edited Text', 42.

20 See Schopen, Buddhist Nuns, 251-68, especially 268 note 62 for references.

21 Hu-von Hinüber, Das Bhikṣuprātimokṣa, pāyattikā 73.

22 Uttaragrantha, Derge 'dul ba Pa $2 \mathrm{~b} .7$ 
who was given five hundred servile laborers; ${ }^{23}$ they refer to 'female and male slaves, bound laborers, and servants' (dāsìdāsakarmakarapauruseya) who come to the community as a part of an inherited estate and which 'are not to be divided but to be set aside as property in common for the Community of Monks from the Four Directions' (avibhājyà cāturdiśāya bhikșusamghāya sādhāraña sthāpayitavyāḥ). ${ }^{24}$ The ownership of humans by the monastic community is also explicitly referred to elsewhere in this Code, where once again they are classified as indivisible:

Moreover, there are five [monastic] properties (vastu, bhāva) which are not sold, which are not separated, not divided, not distributed, not given to another, and are not properly given to anyone. What are they? The property of a vihara, the property of a cell (layana), the Perfume Chamber (gandhakuti) of a complex, the bedding and seats, and the human chattels.

What are the human chattels? The Blessed One said: 'Those who belong to the Community (sämghika) or belong to the stüpa (staupika) are the human chattels.' What are the non-human chattels? Oxen, goats, sheep and buffalo that belong to the Community, or belong to the stüpa, and are said to be authorized by the Blessed One, they are the non-human chattels. ${ }^{25}$

In addition to the sources of servile labor already mentioned, and although it is not explicitly articulated, it remains distinctly possible that in the world of our redactors the acceptance and ownership of villages meant the ownership-in some sense-of their human inhabitants as well, or, at least, the rights to their obligatory labor.

Although more could, and will, be said about the monastic workforce, here it is necessary to point out that it was not necessary for the monastery itself to use its own workforce, and work its own land, for it to be profitable: it could be-and according to our Vinaya

\footnotetext{
23 Schopen, Buddhist Monks and Business Matters, 193-218.

24 Civvaravastu, Dutt, Gilgit Manuscripts, Vol. III, 2, 141.14.

25 Uttaragrantha, Derge 'dul ba Pa 249b.3.
} 
should be-rented out for a share of its yield. In fact, this is the only procedure for exploiting gifted land that our Vinaya explicitly treats in any detail, and it does so in another text in the Uttaragrantha which comes less than eight folios after the text dealing with Śronakoțivimśa and the acceptability of yavāgü. This second text almost certainly alludes to the first, and looks in fact like it might even have been intended as a supplement to the latter, meant to provide the kind of detail that it lacks. Alternatively, given the fact that the second text picked up exactly where the first ends, it is not impossible that the two were originally one text that, for some reason, was subsequently divided. Gunaprabha treats the two texts together in consecutive sūtras. ${ }^{26}$

The Buddha, the Blessed One, was staying in Rajjagṛha, in the Kalandakanivāpa, and when King Bimbisāra gave fields of the size that could be sown with a thousand measures of seed the monks then, after they had eaten the harvest from them, left the fields uncultivated and they became weed patches.

Then when King Bimbisāra went out and saw the fields he said to a minister: 'Alas, who, having left in this way all these fields uncultivated, has turned them into weed patches?'

The minister said: 'Are you not looking at those that could be sown with a thousand measures of seed that the Lord gave to the Noble Ones and they fully accepted?'

The king said: 'But why have these Noble Ones not at least let them out for a share?' The ministers told the monks, and when the monks reported to the Blessed One what had occurred, the Blessed One said: 'The fields belonging to the Community (sämghika) must be let out for a share!'

The monks let them out for a share. ${ }^{27}$

As already noted, the reference here to 'fields of the size that could be sown with a thousand measures of seed' links this text directly to

\footnotetext{
26 Sankrityayana, Vinayasūtra, 95.29.

27 Uttaragrantha, Derge 'dul ba Pa 190b.1-4.
} 
the account of Śronakotivimśa: it is almost certainly a reference to the same fields. Land, incidentally, was frequently measured by the amount of seed required to sow it. ${ }^{28}$

The Sanskrit for 'let out for a share' is, of course, not certain, but Gunaprabha's sūtra discussing our passage has: bhāgenāsya dānam, and when the phrase bhägena prakrayena vā dadyāt occurs, for example, at Arthaśästra 2.12.22 Olivelle translates it as 'he should lease it for a share of the proceeds or lease it out for a fixed rent'. ${ }^{29}$ Although the Tibetan here-thun shas su byin pa-is not frequently met its sense too is not in doubt. Literally it would be 'give $(\sqrt{d} \bar{a})$ for a share (bhāga)', and it corresponds almost exactly to Gunaprabha's Sanskrit. In neither language, however, is it possible to detect a clear distinction between 'lease' and 'rent'. ${ }^{30}$

What we see here in our text might appear to us as a major innovation: the economic exploitation of gifted land by renting it out for a share. It would not be surprising that this might have been felt as a deviation from the ideal, and some indication of this might be seen in-once again-how our redactors told the story of how it came to be. The monk redactors told their fellow monks that the idea of renting out monastery land did not come from them, but from the donor, in this case the king. It is the donor who first presents the idea, and indirectly expresses his expectations, when he asks why the monks have not done so. We frequently find this kind of narrative displacement in this Vinaya in accounts that present other economic innovations or developments: in the account of how monks and nuns came to lend money on interest it was the donors who suggested that they do so; in the account of how monks came to be sellers of expensive fabrics, it was once again the donor who presented the idea. ${ }^{31}$ The redactors repeatedly distance the monks from economic

\footnotetext{
28 Sircar, Studies, 142-54; Dutta, Land System, 36-38.

29 Olivelle, King, Governance, and Law, 128.

30 See Vigasin, 'Remarks on Sanskrit Terms for "Rent".

31 Schopen, Buddhist Monks and Business Matters, 47-49; Vibhangga, Derge 'dul ba Cha 154b.3-155b.2, and Kșudrakavastu, Derge 'dul ba Tha 262b.4263a.6.
} 
innovations or developments and shift the responsibility onto the laity. In virtually every case the monks themselves are represented by the redactors as not inclined to exploit their resources. They do so-other monks are repeatedly told-only to benefit their donors. We will return to this narrative distancing or displacement again. For the moment, notice how the text continues.

While the actual cultivators (karsaka) carried away for themselves everything from each of the fertile fields, the monks did not accept a share. When the monks reported to the Blessed One what had occurred, the Blessed One said: 'You must accept a share of the shares of the field!'

When the monks accepted it but left it right there, the Blessed One said: 'That share must be transported to the vihära!' This being said the cultivator first transported his own. Then the Blessed One said: 'First the land owner's must be transported!'

When they transported it they also stole from it. The monks reported to the Blessed One what had occurred, and the Blessed One said: 'Monks to guard it must be assigned!'

The text then goes on for another page and a half dealing with issues that might arise when the yield is transported by wagon or boat or porter, and ruling on how much and in what way the monks might assist in the work. However interesting these details might be they need not be treated here. Here we might notice one particularly important detail that appears to be missing: the text does not appear to indicate anywhere what the Sangha's share was supposed to be. Yijing — according to Takakusu—says:

According to the teaching of the Vinaya, when a cornfield is cultivated by the Sangha a share in the product is to be given to the monastic servants or some other families by whom the actual tilling has been done. Every product should be divided into six parts, and one-sixth should be levied by the Sangha; the Sangha has to provide the bulls as well as the ground for cultivation, while the Sangha is responsible for nothing else. Sometimes the division of the product should be modified according to the seasons. ${ }^{32}$ 
When Yijing refers here to 'the teaching of the Vinaya' he is almost certainly referring to the Mülasarvastivadda-vinaya, the Vinaya he takes as authoritative and which he took back to China and translated. Unfortunately, a passage that accords with Yijing's interpretation of what 'the Vinaya' says has not been found anywhere in this enormous code, and almost immediately after his remark about the one-sixth, Yijing refers to a division of the produce of monastery land that he actually witnessed at Tamralipti, but here it is divided into three parts and the monks get a full third. ${ }^{33}$ It is true that one-sixth was commonly taken to be 'the king's share', and Yijing may have had that in mind as what fell to the field's owner or, in this case, the Sangha. But Yijing himself indicates any division could at times be modified 'according to the seasons', and in fact probably varied from region to region or from year to year. Given the various factors that might affect the yield it would not necessarily make good business sense to establish a single fixed rate in a document like the canonical Vinaya which would potentially be used in a variety of climates and conditions, and our redactors give numerous indications that they had a good head for business. The absence in our passage of any indication of the size of the monastery's share is very likely to have been intentional. Such an absence is noticeable elsewhere as well.

It is again a great pity that we know so little about share-cropping on monastery land in early India because what evidence we have would seem to suggest that it was widely practiced and may have been very early. Reference to some form of it is made, for example, in at least two other Vinayas. In the Pāli Vinaya the following occurs in Horner's translation:

Now at that time seeds belonging to an Order (sämghika) were sown on ground belonging to an individual (puggalika), and seeds belonging to an individual were sown on ground belonging to an Order. They told this matter to the Lord. He said: 'When, monks, seeds belonging to an Order are sown on ground belonging to an individual,

32 Takakusu, Record, 61.

33 Takakusu, 62. 
having given back a portion, (the rest) may be made use of [bhägam datvā paribhuñjitabbāni]. When seeds belonging to an individual are sown on ground belonging to an Order, having given back a portion, (the rest) may be made use of. ${ }^{34}$

The text here is considerably more obscure than might appear from Horner's translation and this is reflected in part in the significant differences between her translation and the older one of Oldenberg and Rhys Davids. ${ }^{35}$ The first significant problem is the sense of puggalika which Horner translates as 'belonging to an individual', Oldenberg and Rhys Davids as 'belonging to a private person'. These translations are not incorrect but may be misleading. Puggalika is used almost exclusively in contrast with sämghika, and as such invariably refers not to an individual or private layman, but to an individual monk. If that is the case in our passage-and that is highly likely - then our text is dealing with seed belonging to an individual monk planted on land belonging to the monastic Community, and vice versa. A second problem is the meaning of Pâli bhägam datvā, which Horner renders 'having given back a portion', Oldenberg and Rhys Davids: 'when you have given a part'. But if bhāgam datvā means what Sanskrit bhāgena dānam or bhägena dadyāt do-and given the similar contexts it is hard to see how it would not-then the Pāli passage would be saying something more like

He said: 'When, monks, seeds belonging to an individual monk are sown on ground belonging to an Order, having leased it [the land] for a share, it [the produce] must be used [by the Community]!'

Or:

He said: 'When, monks, seed belonging to an individual monk is sown on ground belonging to an Order, having lent it [the seed] for a share it [the share] is to be used [by the Community]!'

34 Oldenberg, Vinaya, i 250.24; Horner, Book of the Discipline, iv 347.

35 Rhys-Davids and Oldenberg, Vinaya Texts, ii 143. 
There are too many possibilities here to arrive at anything like certainty, but what can be said is that the Pāli Vinaya-like the Mülasarvāstivāda-vinaya-also refers both to monastically owned land and to leasing or letting it out for a share of the produce, even if the specific arrangements could be considerably different. But notice too that neither Vinaya indicates the size of the share. It is only in the commentary to the Pāli Vinaya that the share is said to be a tenth. ${ }^{36}$

The Mahiśasaka-Vinaya is a third canonical Vinaya that refers to some form of share-cropping on monastery land. It does so briefly and yet still gives some indication of the size of the share the monastery can get.

Si les läques plantent des légumes sur un terrain du samgha, le samgha, s'il en a besoin, peut leur demander plus d'un tiers. ${ }^{37}$

If the laymen plant vegetables on the Samgha's land, the Samgha, if it has the need, can ask them for more than a third.

We have, then, when given actual numbers for the size of the share, one-sixth (Yijing), one tenth (Pāli commentary, which Oldenberg and Rhys Davids mistakenly give as 'the twelfth part'), and 'more than a third', which indicate in yet another way that the rate could and did vary, and underlines the wisdom and practicality of leaving it unstated in the canonical rule. Beyond that, the presence in three separate Vinayas of reference to some form of share-cropping on monastery land may have chronological implications. Many scholars seem to think that the Pâli Vinaya is the earliest of such codes, and that the Mülasarvasstivada-vinaya is the latest. If this were to prove true-though there is room to doubt that it will-that could mean that some form of share-cropping on monastic land was known from the earliest Vinaya to the latest, and to one or more in between.

Our redactors, finally, seem also to have been fully aware that

36 Horner, Book of the Discipline, iv, 347, note 2.

37 Jaworski, 'La section de la nourriture', 91. 
with the ownership of land came potential problems, both legal and otherwise. Their Vinaya contained two separate versions of what in Pāli is the Aggañna-sutta, the partially tongue-in-cheek account of the evolution of the human world and its institutions. Here, greed and hoarding lead to fields being marked out, boundaries fixed, and boundary markers established (kșetrāni māpayema sìmām badhnìāma maryādām sthāpayema). ${ }^{38}$ From that, of course, theft and dispute inexorably followed. In any case once the monastic Community acquired land it was probably inevitable that boundary disputes would arise and would have to be addressed. A little text in the Uttaragrantha is an example of how they were addressed:

A resident (naivasikika) monk was having a field that belonged to the Community plowed, and very close to that a householder was also plowing his field. The householder came over and said: 'Reverend you must not plow my field!'

'This is not yours-it is a field that belongs to the Community.'

'Reverend, my ownership can be shown even without a witness.' Saying that, the householder dug up the stakes that had been previously pounded in at the boundaries, and having dug them up he showed them to him. The monk, then, when the plowman had left, and after the householder had gone, moved the stakes in and plowed the field.

When the householder returned he said: 'Reverend even now when I have prevailed why do you still plow the field?'

When the monk gave rise to remorse the Blessed One said: 'If the matter is completed it would be an extremely serious offence (pāräjika). ${ }^{39}$

Our redactors appear to have taken a very dim view of meddling with boundary markers, making it a kind of theft and therefore one of the four most serious monastic offenses, any one of which results in a monk losing the status of a monk. Manu too took a similarly

\footnotetext{
38 Gnoli, Gilgit Manuscript of the Sanghabhedavastu, i, 14.4.

39 Uttaragrantha, Derge 'dul ba Pa 2b.7.
} 
dim view of it. 'Anyone', he says, 'who destroys boundary markers [maryādābhedaka] shall be executed with mutilation'. ${ }^{40}$

The Uttaragrantha obviously deals only with monastic infringement on lay land. A case of the reverse was cited by Gernet from the Sarvāstivāda-vinaya:

A layman had repeatedly used the monks' field without paying rent (sbui) to the community. When this layman was about to sow again, an old bhiksu went to him and said: 'You have repeatedly used our fields without paying the rent. Therefore do not sow, or, if you wish to sow, you must pay.' After these words, the layman made ready to plow his furrows. The old bbiksu then lay down on the soil to stop the plow. The layman, greatly annoyed, desisted. ${ }^{41}$

If nothing else, the text here suggests that some techniques of passive resistance have not changed over time, but more importantly it points to the fact that the monks would have had few means to enforce their claims, especially since taking laymen to court was normally not an option and strongly disallowed. Notice too that even though the old bhikșu's action succeeded it did so at the cost of greatly annoying the layman. Either way, then, land ownership caused friction, and friction with the laity was precisely what so many other monastic rules were designed to avoid.

There is one last thing that might be mentioned here. Both the canonical Vinaya and scholiasts like Gunaprabha associate the monastic acceptance of land with the monastic acceptance of domestic animals, and although there is limited textual claim for the latter it is worth a brief look. We have already seen that in the story of the first gift of land by king Pradyota, that gift was accompanied by the gift of the 'auxiliaries of the means of subsistence', and that these were explicitly defined as 'oxen, buffalo, goats and sheep'. We have also seen, in a passage detailing types of indivisible property, explicit acknowledgement that the Saingha owned 'oxen, goats, sheep and

40 Olivelle, Manu's Code, 9.291; see also 8.246-266.

${ }^{41}$ Gernet, Buddhism in Chinese Society, 96-97. 
buffalo'. In the Civvaravastu, in a text describing how property in an estate that the Sangha inherited should be handled, we see not only that this was one possible source for such animals-buffaloes, goats and sheep are listed-but also that the Buddha is made to rule that they become 'property in common for the Community of Monks from the Four Directions and are not to be distributed'. ${ }^{42}$ Apart from passages like these, however, very little else is said about these animals or about how they were used or their role in the monastic economy. The oxen and buffalo were likely used as draft animals-according to Yijing, as we have seen, the Sangha had to provide the 'bulls' in any sharecropping agreement-but both could have contributed milk as well. The Arthaśästra, for example, refers to milking buffalo, but also goats and sheep. It also refers to collecting the wool of sheep and goats, ${ }^{43}$ and herds or flocks of these would, if they were of any size, almost certainly have produced far more than the monastery could use. Any surplus then might well have been sold.

Inscriptional references to the gift of domestic animals to the monastery are not particularly common, but there are at least two from early Andhra and both refer to large herds. One from Alluru of perhaps the second century-sadly fragmentary-refers to 'five hundred cows, sixty-four bullocks and carts'. ${ }^{44}$ Given that the Arthaśästra defines a herd as at least ten, ${ }^{45}$ this would seem to be a very large herd. Not quite so large but still impressive is the herd of one hundred and fifty cows that an inscription from Phanigiri of about the fourth century records as the gift of a monk and vinaya master named Dhammasena and his relatives. The wording of this record and the terms of the agreement it records are important because they reveal that the cows were meant to continually provide kārsāpanas or cash, and cows of course cannot do that - that would require that what they do provide be sold for cash. The record says:

42 Schopen, Buddhist Monks and Business Matters, 118.

43 Olivelle, King, Governance, and Law, 2.29.35 and 2.29.41.

44 Sankaranarayanan, 'A Brahmi Inscription', 87-89.

45 Olivelle, King, Governance, and Law, 4.10.16. 
Having been conveyed from one and the same (i.e., Dhammasena), this religious gift was permanently established for repairs and maintenance and for a canopy of flowers every year at the Pavarana festival, (to wit): 150 cows, 150 taridelas are handed over. From that (tato-i.e. the income produced from the herd) the Community of monks must every year buy the flowers (puphamolam), and must give 6 kāhäpanas for 4 sánikas (measures/pots) of lamp oil. This must be carried out without breaching the agreement.........

Professor von Hinüber has understood this difficult record somewhat differently, but it seems fairly certain that the wording and construction here should be understood in light of the numerous parallels from the Western caves where given land was expected to produce cash: here too, as we have already seen, a field might be given, but then it is said: 'And from that (eto) the sum of twelve as cloth money' is to be given to a monk who resides in a given cell. In this instance Bühler padded out eto with 'out of (the rent of) that'. Whether it is a field or herd, then, the wording of these records assumes but conceals several intermediate steps between the exploitable asset and the desired funds. Unfortunately, who manages the assets, and how that is done, are not often clear, but when there are any indications, it is the monastery itself or its officers that frequently appear in the role of manager. A series of donations recorded in two twelfth century inscriptions on pillars from Amaravati, however, would seem to suggest yet another sort of arrangement. Here we find, for example:

... Koṭaketarāja ... gave for his own merit to the Holy God Buddha (śrimadbuddhadeva) 110 sheep for two perpetual lamps. Having received fifty-five sheep among these, Dāmaka-Amare-Boya with his sons and further descendants has to supply daily one māna of ghee as long as the moon and the sun shall last. Having received (the remaining) fifty-five sheep, Kete-Boya ... has to supply etc. ${ }^{47}$

\footnotetext{
46 von Hinüber, 'Again on the Donation Made by Dhammasena', 6-7.

47 Hultzsch, 'Two Pillar Inscriptions', 156.
} 
Here, it would seem, a third party-a local layman and herder-actually managed the assets that belonged to 'The Holy God Buddha', and presumably kept for himself what was left over after supplying the monastery every day with a set amount of ghee.

These late records from Amaravati might also suggest a specific link between the gift of domestic animals that produce milk and the endowment of perpetual lamps at Buddhist shrines. In fact, the same sort of linkage is found in a much earlier record from Bodhgayā which has been assigned to the sixth or seventh centuries. The inscription is fragmentary but certainly says:

And right here every day, for as long as the sun, the moon, and the stars last, a butter lamp has been provided for the Blessed One, the Buddha, through the gift of a hundred cows. And arrangements were made through another hundred cows for attending to the repairs and maintenance of the temple and a butter lamp every day for that image. ${ }^{48}$

Here too the gifted animals constitute what appears to have been a large herd, and reference to a hundred more may have been lost according to Bloch's restoration.

In the end then-and that is where we are-what are we to make of all of this? Seen in isolation, the stories cited here might seem to be little more than random stories told by Vinaya masters to explain to other monks why they do what they do. They do not seem to be a part of a larger project or comprehensive plan. Gunaprabha, however, linked these stories about how the Sangha had acquired exploitable assets with stories about how it acquired a reliable workforce: servants, menials and slaves that the monastery had to feed and house; children who were to be 'protected' by the monastery for a fee, or were given outright to individual monks

48 Bloch, 'Notes on Bodh Gayā', 153. 
as menials. ${ }^{49}$ And these in turn can be linked to other stories about the propriety of monks with certain skills engaging in craft-work and menial chores to reduce the monastery's dependence on outside sources and services. There are stories about how the Buddha came to authorize lending money on interest by both monks and nuns, how he came to authorize the acceptance of cash by monks from deposits made by donors with merchants; stories about the monastery running a granary and selling rice under market value, about it selling space in the monastic complex, or certain kinds of luxury cloth received as donations, about monastic auctions to liquidate the estates of dead monks or to convert other donations into cash; stories about organized fund drives and publicly advertised image processions meant to generate 'donations', and this enumeration is only a sample: it is nothing like a comprehensive list. It alone, however, indicates already that a good deal of thought and a great deal of space in this Vinaya was given over to business matters. Slightly rephrased, this sample makes it clear that our passages dealing with the Sangha acquiring permanent productive assets are only a very small part of a very large series of texts in this Vinaya dealing with what might reasonably be called the business model of a Buddhist monasticism. The fact that these texts are widely scattered and dispersed in this enormous code, and the fact that the model was never presented in a systematic fashion, does not make that model any less comprehensive. Indeed, the fact that texts articulating some aspect or component of this model are so widely scattered and can be found in every part or section of this Vinaya indicates, rather, how deeply embedded and pervasive it is there.

A presentation of the specifics or details of this model will have to wait until more studies are done on individual topics, but certain overarching elements are already visible, one very clearly so even in our texts on acquiring productive assets, and it is one that bears on the purpose of this Buddhist monasticism. As we have seen, these texts-whatever else they might be-are stories that the monks who wrote or compiled this Vinaya told other monks about how and

\footnotetext{
49 Sankrityayana, Vinayasūtra, 95.27.
} 
when the Buddha himself directed that their community accept and own permanent properties, productive lands, and profitable herds. But in their stories they more often than not also tell their monks why the Buddha did so, and thereby provided not just an explanation, but a rationale and justification for monastic behavior and their business model. As we have seen, Mūlasarvāstivādin monks were told that when the monks in Vairambhya were instructed not to destroy the huts, and thereby acquire permanent property, it was not because the monks needed or wanted it, or because it would contribute to their religious life and practice, but because it would provide their benefactors and donors with an ongoing source of merit. Mūlasarvāstivādin monks were told that the acceptance and ownership of villages, agricultural lands, and herds of domestic animals were authorized not because the monks were in need of them, or because they would contribute to the individual monk's religious progress, but 'out of concern for' or the 'benefit of lay donors, and because it would increase the use of what they provide, and therefore their merit. The monks were told that it was not their idea to lease out monastic land for a share of the produce, but that it was the donors' idea; they expected the lease of land and were displeased when the monks allowed productive fields to fall into ruin. The same or similar stories are in fact told in this Vinaya about a long series of enterprises that monks are instructed to engage in, and although each of these will need to be looked at in detail-like acquiring productive assets was here-even a brief survey is useful. Mūlasarvāstivādin monks were told, for example, that it was not their idea to accept permanent endowments and to lend money on interest, and they were instructed to do so by the Buddha not for their benefit, but for the benefit of their donors who are anxious about what would happen to their monasteries (and their merit) after their death. ${ }^{50}$ An even more complex financial arrangement required monks to accept cash that was generated from a deposit made for their benefit with a merchant, but this arrangement-numerous examples of which can be seen in inscriptions-was not devised for their benefit, the monks were told,

\footnotetext{
50 See note 31 above.
} 
but to ensure that the gifts of royal lady donors would be utilized. ${ }^{51}$ Mūlasarvāstivādin monks were told that the Buddha allowed monks to sell space in the monastery complex to pious donors who wanted to build their own religious facilities there-often called in inscriptions cetiyakutis - not to generate cash but because devout donors wished to do so. ${ }^{52}$ They were told that the Buddha had instructed monks to in effect set up a granary and sell rice not to generate a profit but in order to serve traveling merchants who wished to feed the monks. ${ }^{53}$ They were told that selling for cash expensive cloth that had been given to the Community was not their idea, but the donors. ${ }^{54}$ Both the ideas of organized fund drives and of image processions, which ended with a monastic auction of the donations received, came-the monks were told-from lay donors, not the monks. ${ }^{55}$ Looking after children, for which the monks were paid, was presented as a service to the laity, not a money-making enterprise. ${ }^{56}$ Obviously, then, although the specific details will vary the themes of lay instigation and donor benefit remain remarkably consistent: they are involved and invoked, in one way or another, in almost every story that Mūlasarvāstivādin monks told themselves, and each other, about how they came to be involved in profit-taking activities. Our problem, however, remains: how to best explain these constant assertions that profit-making activities were undertaken by the monks at the suggestion or prompting of lay donors, and that they did so to meet the needs of and benefit those same donors, and not themselves. Here, it seems, there are at least two broad possibilities, one somewhat cynical, the other somewhat surprising.

The cynical possibility has already been sketched. Assuming-and it is only an assumption-that the redactors of our code saw the economic activities they were presenting as radical innovations and

\footnotetext{
51 Ksudrakavastu, Derge 'dul ba Tha 258a.3-259a.3.

52 Gnoli, Gilgit Manuscript of the Śayanāsanavastu, 33.8.

53 Bhikșu-vibhanga, Derge 'dul ba Cha 156b.4-157a.4

54 See above note 31.

55 Schopen, Figments and Fragments, 133-36.

56 Schopen, Buddhist Nuns, 140-53.
} 
marked departures from an original monastic ideal, it would be distinctly possible that they told their stories in the way they did in order to shift the responsibility for these 'innovations' and 'developments' away from the monks onto lay donors and benefactors. A second broad possibility is that the redactors of our Code told the stories in this way because they believed that that was how these developments occurred, and because they wanted to promote a particular vision or version of what Buddhist monasticism was and should continue to be. To represent the Buddha himself as fashioning a community in response to lay prompts and needs would send a powerful message to ordinary monks in regard to how they should proceed in their own time and location. But what must be at least a little surprising is how very different the vision of monasticism embedded in these stories is from the version usually found in our handbooks. The stories told in our Vinaya present a monasticism that is not particularly focused on furthering the religious life and progress of the individual monk, but one meant to meet the needs and to address the anxieties and concerns of its lay supporters. This is a monasticism in the service of the laity, monasticism that was organized and run as a business that was involved in a wide range of economic activities, and this was the monasticism that-according to our stories-was authorized by the Buddha himself.

\section{Bibliography}

\section{Primary Sources}

Barber, A. W. The Tibetan Tripitaka. Taipei Edition. Taipei: SMC Publishing, 1991.

Dutt, N. Gilgit Manuscripts. Vol. III, Parts 1-4. Calcutta: Calcutta Oriental Press, 1942-1950.

Gnoli, Raniero. The Gilgit Manuscript of the Sanghabhedavastu, Parts 1 and 2. Rome: Istituto Italiano per il Medio ed Estremo, 1977-1978.

- - - The Gilgit Manuscript of the Śayanāsanavastu and the Adhikaranavastu. Rome: Istituto Italiano per il Medio ed 
Estremo Oriente, 1978.

Horner, I. B. The Book of the Discipline (Vinaya-Pitaka). Vols. 1-5.

London: Pali Text Society. 1938-1966.

Hu-von Hinüber, Haiyan. Das Bhiksu-prātimokșasūtra der

Mūlasarvāstivādins [The Bhikṣu-Prātimokșasūtra of the

Mūlasarvāstivādins]. FreiDok plus Universitätsbibliothek Freiburg

[FreiDok and the Freiburg University Library]. https://freidok.

uni-freiburg.de/data/9535. 2003.

Jaworski, Jan. 'La section de la nourriture dans le Vinaya des

Mahīśāsaka' [The section on food in the Mahīśāsaka Vinaya].

Rocznik Orjentalistyczny [The Yearbook of Oriental Studies] 7

(January 1929-1930): 53-117.

La Vallée Poussin, Louis de. L'Abhidharmakośa de Vasubandbu

[Vasubandhu's Abhidharmakośa]. T. I-VI. Paris-Louvain:

Geuthner, 1923-1931.

Oldenberg, H. The Vinaya Pitaka. Vols. 1-5. London: Williams and

Norgate and Pali Text Society, 1879-1883.

Olivelle, Patrick. King, Governance and Law in Ancient India:

Kautilya's Arthaśástra. Oxford: Oxford University Press, 2013.

-_- Manu's Code of Law. Oxford: Oxford University Press, 2005.

Pradhan, Prahlad. Abbidbarmakośabhāsyam of Vasubandhu. Patna:

K. P. Jayaswal Research Institute, 1975.

Rhys Davids, T. W., and H. Oldenberg. Vinaya Texts. Vols. 1-3.

Sacred Books of the East 13, 17, 20. Oxford: Oxford University

Press, 1881-1885.

Sankrityayana, Rahul. Vinayasutra of Bhadanta Gunaprabba.

Bombay: Bharatiya Vidya Bhavan, 1981.

Schopen, Gregory. 'Hierarchy and Housing in a Buddhist Monastic

Code. A Translation of the Sanskrit Text of the Sayanāsanavastu

of the Mülasarvāstivāda-vinaya'. Buddhist Literature 2 (2000):

92-196.

Shōno, Masanori. 'A Re-edited Text of the Varșāvastu in the

Vinayavastu and a Tentative Re-edited Text of the Vārșikavastu

in the Vinayasütra'. Acta Tibetica et Buddhica 3 (2010): 1-128.

Takakusu, Junjirō. A Record of the Buddhist Religion as Practiced

in India and the Malay Archipelago (A.D. 671-95) by I-Tsing.

Oxford: Clarendon Press, 1896. 


\section{Secondary Sources}

Bloch, T. 'Notes on Bodh Gayā'. In Annual Report of the Archaeological Survey of India for the Years 1908-09, by the Government of India, 139-58. Calcutta: Superintendent Government Printing, 1912.

Burgess, James. Report on the Elura Cave Temples and the Brabmanical and Jaina Caves in Western India. London: Trübner, 1883.

de Jong, J. W. 'Les sūtrapițaka des Sarvāstivādin et des Mūlasarvāstivādin' [The sütrapițaka of Sarvāstivādin and Mūlasarvāstivādin]. In Mélanges d'indianisme a la mémoire de Louis Renou [Collection of Indianism in Memory of Louis Renou], 395-402. Paris: Éditions E. de Boccard, 1968.

Dutta, Saroj. Land System in Northern India, c. AD 400-c. AD 700. New Delhi: Munshiram Manoharlal, 1995.

Foucher, A. La vie du Bouddha d'après les textes et les monuments de l'Inde [The life of the Buddha from the texts and monuments of India]. Paris: Adrien Maisonneuve, 1987.

Gernet, Jacques. Les aspects économiques du bouddhisme dans la société chinoise du $V^{e}$ au $X^{e}$ siècle [Economic aspects of Buddhism in Chinese society from the fifth to tenth centuries]. Paris: École française d'Extrême-Orient, 1956.

- - . Buddhism in Chinese Society. An Economic History from the Fifth to the Tenth Centuries, translated by Franciscus Verellen. New York: Columbia University Press, 1995.

Hiraoka Satoshi 平岡聡. Setsuwa no kōkogaku: Indō bukkyō setsuwa ni bimerareta shisō説話の考古学: インド仏教説話に秘められた 思想 [Archaeology of Narratives: Thoughts hidden in Indian Buddhist Narratives]. Tokyo: Daizō Shuppan 大蔵出版, 2002.

Hultzsch, E. 'Two Pillar Inscriptions of Amaravati'. Epigraphia Indica [Archaeological Survey of India] 6 (1900-1901): 146-60.

Sankaranarayanan, S. 'A Brahmi Inscription from Alluru'. Sri Venkateswara University Oriental Journal 20 (1977): 75-89.

Senart, E. 'The Inscriptions in the Caves at Nasik'. Epigraphia Indica [Archaeological Survey of India] 8 (1905-1906): 540-96.

Schopen, Gregory. Bones, Stones, and Buddhist Monks. Honolulu: 
University of Hawai'i Press, 1997.

-_- Buddhist Monks and Business Matters. Honolulu:

University of Hawai'i Press, 2004.

-_- Buddhist Nuns, Monks, and Other Worldly Matters.

Honolulu: University of Hawai'i Press, 2014.

- - Figments and Fragments of Mahāyāna Buddhism in India.

Honolulu: University of Hawai'i Press, 2005.

Sircar, D. C. Studies in the Political and Administrative Systems in

Ancient and Medieval India. Delhi: Motilal Banarsidass, 1974.

Vigasin, Alexi A. 'Some Remarks on Sanskrit Terms for "Rent",

"Lease", "Hired Labour", and "Employment". In Studies in

Indology and Musicology. Dr. P. N. Kawthekar Felicitation

Volume, edited by Sushma Kulshreshtha and J. P. Sinha, 361-64.

Delhi: Pratibha Prakashan, 1993.

von Hinüber, Oskar. 'Again on the Donation made by the

Vinayadhara Dhammasena and on other Inscriptions from

Phanigiri'. Annual Report of the International Research Institute for Advanced Buddhology at Soka University for the Academic Year 201216 (2013): 3-12. 